\title{
Local ecological knowledge of the threatened Cochin Forest Cane Turtle Vijayachelys silvatica and Travancore Tortoise Indotestudo travancorica from the Anamalai Hills of the Western Ghats, India
}

\author{
Arun Kanagavel ${ }^{1,2,3}$ \& Rajeev Raghavan ${ }^{1,3,4}$ \\ ${ }^{1}$ Conservation Research Group (CRG), St. Albert's College, Kochi, Kerala 682018, India \\ ${ }^{2}$ Wildlife Information Liaison Development Society (WILD), ${ }^{4}$ Zoo Outreach Organization (ZOO), \\ 96 Kumudham Nagar, Vilankurichi Road, Coimbatore, Tamil Nadu 641035, India \\ ${ }^{3}$ Durrell Institute of Conservation and Ecology (DICE), School of Anthropology and Conservation, University of Kent, Canterbury, \\ CT2 7NR, United Kingdom \\ Email: ${ }^{1}$ arun.kanagavel@gmail.com (corresponding author), ${ }^{4}$ rajeevraq@hotmail.com
}

Date of publication (online): 26 October 2012 Date of publication (print): 26 October 2012 ISSN 0974-7907 (online) | 0974-7893 (print)

Editor: S. Bhupathy

Manuscript details:

Ms \# 03003

Received 14 November 2011

Final received 28 August 2012

Finally accepted 06 October 2012

Citation: Kanagavel, A. \& R. Raghavan (2012). Local ecological knowledge of the threatened Cochin Forest Cane Turtle Vijayachelys silvatica and Travancore Tortoise Indotestudo travancorica from the Anamalai Hills of the Western Ghats, India. Journal of Threatened Taxa 4(13): 31733182

Copyright: ๑) Arun Kanagavel \& Rajeev Raghavan 2012. Creative Commons Attribution 3.0 Unported License. JoTT allows unrestricted use of this article in any medium for non-profit purposes, reproduction and distribution by providing adequate credit to the authors and the source of publication.

For Author Details, Author Contribution and Acknowledgements see end of this article.

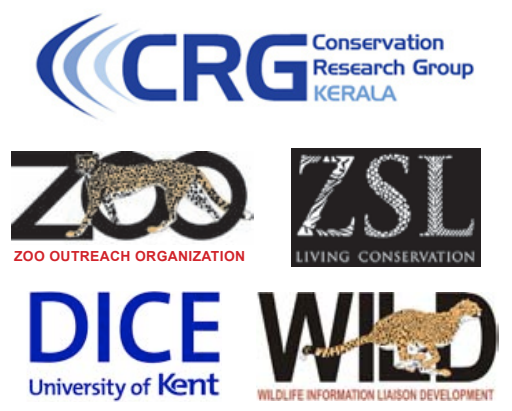

ZooBank urn:Isid:zoobank.org:pub:A44F15BEE829-4D6B-A64C-6CB03D9CDD26

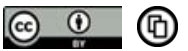

OPEN ACCESS | FREE DOWNLOAD
Abstract: In this study, we used local ecological knowledge to determine the status, habitats, threats and consumption of two range-restricted and threatened chelonians, Vijayachelys silvatica and Indotestudo travancorica from two forest divisions of Kerala, that occur in the Western Ghats. Of these terrestrial species, I. travancorica was more abundant, preferred and consumed in the study region. Fire was the major perceived threat to these species, followed by human consumption. Contrary to the literature, $V$. silvatica was considered common and encountered more often during the fruiting season of specific plants, and in areas where temperatures were low. We also found that photographs, rather than local names, were important for species identification associated with such knowledge surveys.

Keywords: Chalakudy, Indotestudo travancorica, Kadar, Malayar, Vazhachal, Vijayachelys silvatica

\section{INTRODUCTION}

Chelonians comprise one of the world's most endangered vertebrate groups and are next only to primates in terms of the impending risk of extinction (Hoffmann et al. 2010). Turtle populations are incessantly declining due to their use on a massive anthropological scale as food, traditional medicines and pets; seldom accounting for their sustainability (Turtle Conservation Coalition 2011). In India, which is among the top five priority countries in Asia for chelonian conservation (Stuart \& Thorjarnarson 2003), commercially driven collection and consumption of turtles is extensive around the central and northeastern states. Noncommercial use and small-scale trade is widespread and includes among others, the local use of turtle shell and blood for curing body ailments (Bhupathy \& Choudhury 1995; Gupta 2000; Deepak \& Vasudevan 2009; Pasha et al. 2009). These issues are however largely understudied and

The publication of this article is supported by the Critical Ecosystem Partnership Fund (CEPF)

-- a joint initiative of I'Agence Française de Développement, Conservation International, the

Global Environment Facility, the Government of Japan, the MacArthur Foundation and the World Bank. 
neglected (Pasha et al. 2009).

Of the 28 species of tortoise and freshwater (including terrestrial) turtles known from India, 40\% are threatened (Das 1991; CFH/MCBT 2006). Detailed ecological information on numerous species, including common and widely distributed forms such as Lissemys punctata (Bhupathy \& Vijayan 1993, 1994) and Melanochelys trijuga (Bhupathy 2009; Das \& Bhupathy 2009; Krishnakumar et al. 2009) and range-restricted species such as Vijayachelys silvatica and Indotestudo travancoria is scanty (see Deepak et al. 2011). Quantitative studies on the impact of various kinds of threats to chelonians are also lacking.

Information on the ecology and use of $V$. silvatica and $I$. travancoria has been previously gathered around the forests of Chalakudy in Kerala from the Kadars, an indigenous seminomadic huntergatherer community (Vijaya 1982a; Vijaya 1984; Appukuttan 1991) with a population of 1500, living in 24 settlements across the landscape (Bachan et al. 2011). The Malayars, another indigenous community who are fewer in number than the Kadars in the same landscape, are more inclined to agriculture as a source of livelihood. Both these indigenous communities currently lead a more urbanised lifestyle from reduced interaction with forests (Bachan et al. 2011). A large nonindigenous population also exists in the vicinity of these forested areas. The main source of income for local communities in this region is through both fulltime or part-time employment in plantations, the State Forest Department and tourism activities around the Athirapilly Waterfalls.

The presence of such local communities provides an opportunity to understand various biodiversity issues through local ecological knowledge (LEK) which is especially vital in case of cryptic species that are difficult to detect. The information gathered during an individual's lifetime from personal observations and experiences has facilitated informing the ecology, distribution and threats to numerous species (Gilchrist et al. 2005; Ravaloharimanitra et al. 2011; Lescureux et al. 2011). We used LEK of these indigenous and nonindigenous communities in the Anamalai Hills of the Western Ghats to document local names, perceived abundance, consumption and threats to the endemic forest-dwelling chelonians of the region, the Endangered Cochin Forest Cane Turtle V. silvatica (Asian Turtle Trade Working Group 2000a; Image 1)

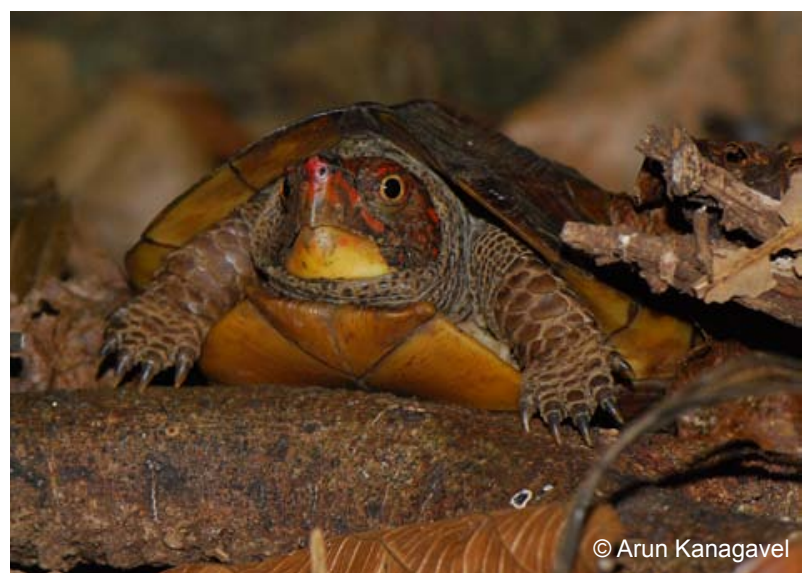

Image 1. Cochin Forest Cane Turtle Vijayachelys silvatica at Chalakudy Forest Division

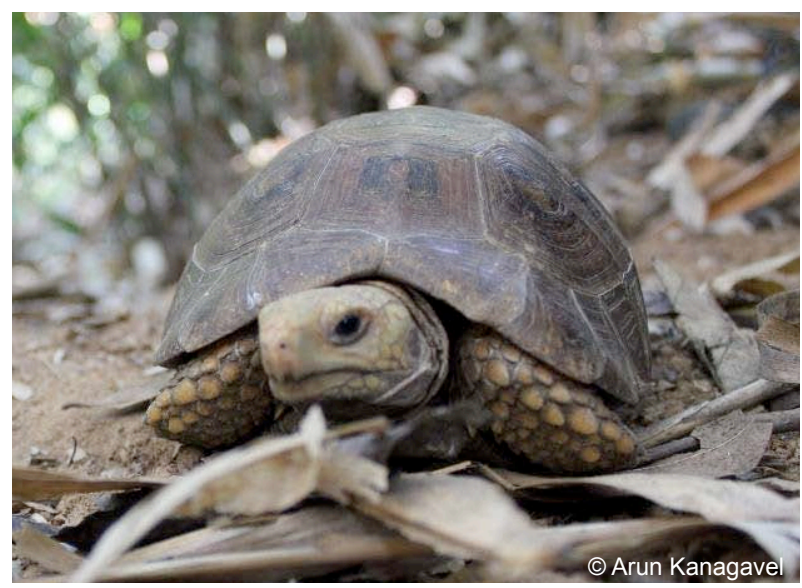

Image 2. Travancore Tortoise Indotestudo travancorica at Vazhachal Forest Division

and Vulnerable Travancore Tortoise I. travancorica (Asian Turtle Trade Working Group 2000b; Image 2). Since $V$. silvatica, was perceived to be lesser known, rarer/more difficult to detect and the most threatened of the forest-dwelling chelonians in the region, we also attempted to gather any additional information, especially on their ecology, status and occurrence that would inform future surveys.

\section{Study Area}

We surveyed five forest ranges, namely, Athirapilly, Sholayar, Vazhachal, Kollathirumedu and Vellikulungara of the Vazhachal $\left(10^{\circ} 07^{\prime}-10^{0} 23^{\prime} \mathrm{N}\right.$ \& $\left.76^{0} 09^{\prime}-76^{0} 54^{\prime} \mathrm{E}\right)$ and Chalakudy $\left(10^{\circ} 10^{\prime}-10^{\circ} 28^{\prime} \mathrm{N}\right.$ \& $\left.76^{0} 05^{\prime}-76^{0} 37^{\prime} \mathrm{E}\right)$ forest divisions in the Anamalai Hills of the southern Western Ghats (Fig. 1). Much of the research on $V$. silvatica has been conducted in these forest divisions (Vijaya 1982a; Moll et al. 1986; 


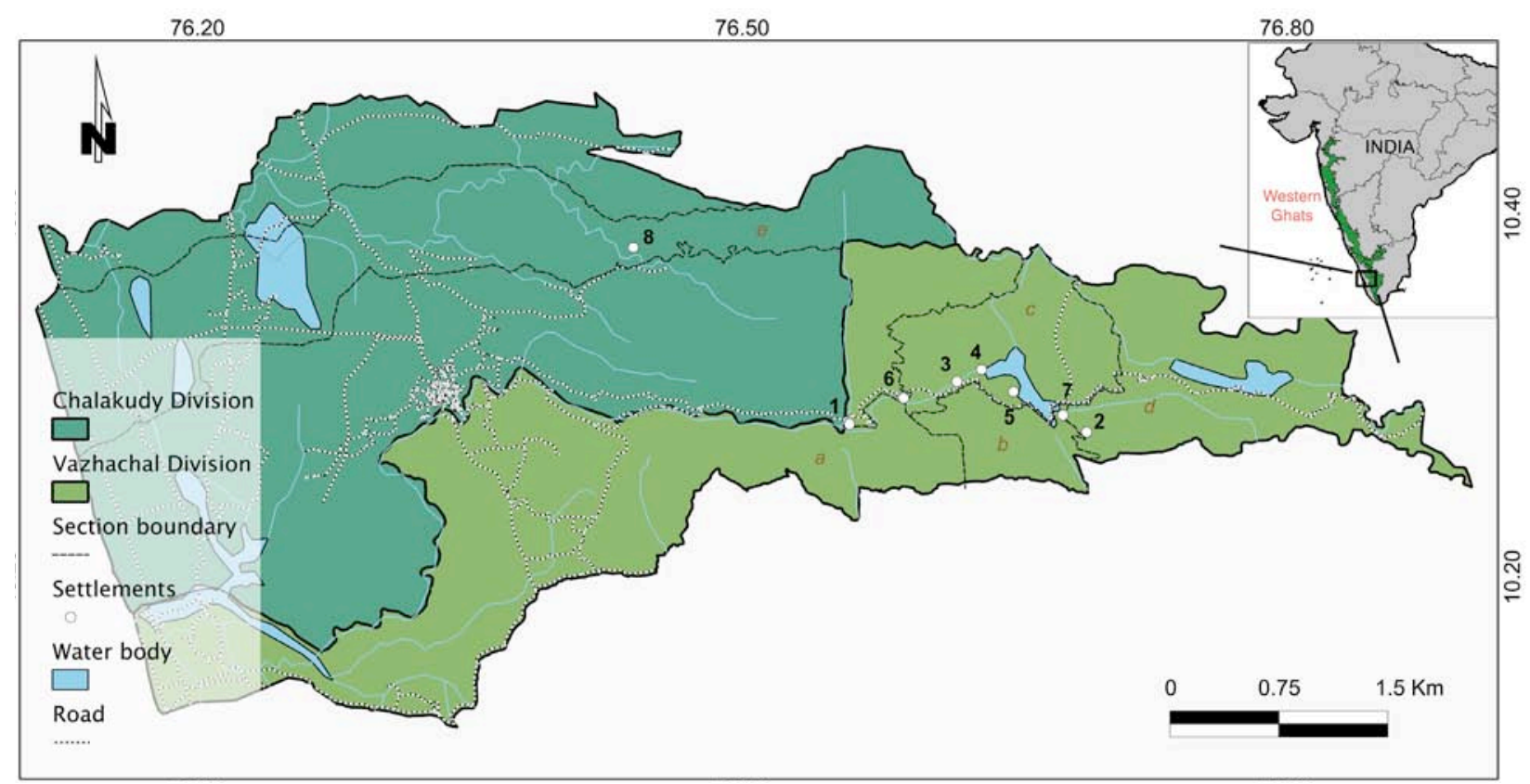

Figure 1. Map of the study area and the surveyed human settlements and forest ranges (see Appendix 1) in the Western Ghats

Appukuttan 1991).

These forest divisions are also located adjacent to the Parambikulam Tiger Reserve and the Chimmony Wildlife Sanctuary and come under the drainage system of two rivers, Chalakudy (and its tributaries including Sholayar and Karappara) and Karuvannur (Mupilli Tributary). The area receives an average rainfall of $4019 \mathrm{~mm}$ and sustains moist evergreen, semievergreen and deciduous vegetation in addition to Teak Tectona grandis and Bamboo Ochlandra travancorica plantations managed by the forest department (James et al. 2011). The State Highway 21 (connecting Chalakudy Town with the state border) as well as restricted-access motorable pathways and footpaths occur here. Two hydroelectric dams, Poringalkuthu and Sholayar already exist in this landscape, while the construction of a dam in the Athirapally-Vazhachal area is currently uncertain due to resistance from environmental activists (Nair 2011).

\section{METHODS}

Unnamed colour photographs of three species- $I$. travancorica, V. silvatica and Lissemys punctata (Indian Flap-shelled Turtle) — represented as a complete side profile with an inset of a distinct characteristic were shown one after another to respondents, who were first requested to identify them individually. Lissemys punctata being a lesser-concern species (Asian Turtle Trade Working Group 2000c) was included in the survey to derive comparisons with the two threatened species. The Indian Black Turtle Melanochelys trijuga, that might be common here was not included in the present study due to its morphological similarity with $V$. silvatica, so as to reduce any sampling errors (Anadón et al. 2009). Local names used for the species while identifying them was noted and respondents were asked to rank the abundance of the three species. After determining whether respondents consumed chelonian meat, they were asked to rank the three species based on preference and extent of consumption. Respondents were also asked if deforestation, forest-fires, roads or any other factor threatened wild populations of the forest-dwelling species. Age, gender and ethnicity of each respondent was also sought.

Questionnaires were administered at villages selected through a convenience sampling strategy (Newing 2010) for gathering information pertaining to LEK from December 2010 to March 2011 with the help of local informants. The survey was conducted in the local language (Malayalam) and from each household, a single individual above the age of 18 years was selected after he/she consented to be interviewed. With 
specific regard to $V$. silvatica, open-ended questions were used to determine their local sites of occurrence as well as the environmental conditions and seasons in which they had been sighted. Respondents were asked whether this species was rare or common in the wild (including a "Don't Know" option) and whether its population was reducing (including "Maybe" and "Don't Know" options).

\section{Analysis}

Results were analysed using SPSS 11.5 for Windows. Kruskal-Wallis and Mann-Whitney U-test (Zar 2010) were used to determine whether there were differences in perceived species abundance across different forest ranges. These tests were also used to check for differences in chelonian consumption across forest ranges, settlements and socio-economic characteristics (age, gender and ethnicity) of respondents.

\section{RESULTS}

A total of 72 questionnaires were administered at eight local settlements (Appendix 1). The majority of the sample were Kadars $(n=44)$, followed by Malayars $(n=17)$ and only 11 nonindigenous local inhabitants. Most of the respondents were male $(n=60)$ and over 40 years old $(\mathrm{n}=57)$. All the respondents confirmed the occurrence of I. travancorica and V. silvatica while six out of 72 respondents had not seen $L$. punctata in the landscape.

While respondents identified $V$. silvatica and L. punctata, with single, distinct local names, $I$. travancorica was associated with four local names including one that was also used for $V$. silvatica (Table 1). The chelonian that was perceived to be most abundant in the area was I. travancorica followed by
V. silvatica and L. punctata (Fig. 2). The perceived abundance of these species did not vary among forest ranges.

Indotestudo travancorica was the most commonly consumed species followed by $V$. silvatica and $L$. punctata (Fig. 4). There was no significant difference between the species preferred for consumption and those that were most consumed. There was also no significant difference in chelonian consumption across the different forest ranges, settlements or social attributes of respondents. Forest fires and predation by a range of wild animals including the Asiatic Wild Dog Cuon alpinus, Leopard Panthera pardus, Wild Boar Sus scrofa and Tiger Panthera tigris were thought to be the major threats to forest-dwelling chelonians (Fig. 3). Consumption of chelonians was widespread (87.5\%) among the respondents and almost on par with the perception of fire as a threat (Fig. 3). Chelonian mortality, especially in I. travancorica due to trampling by the Asian Elephant Elephas maximus was also

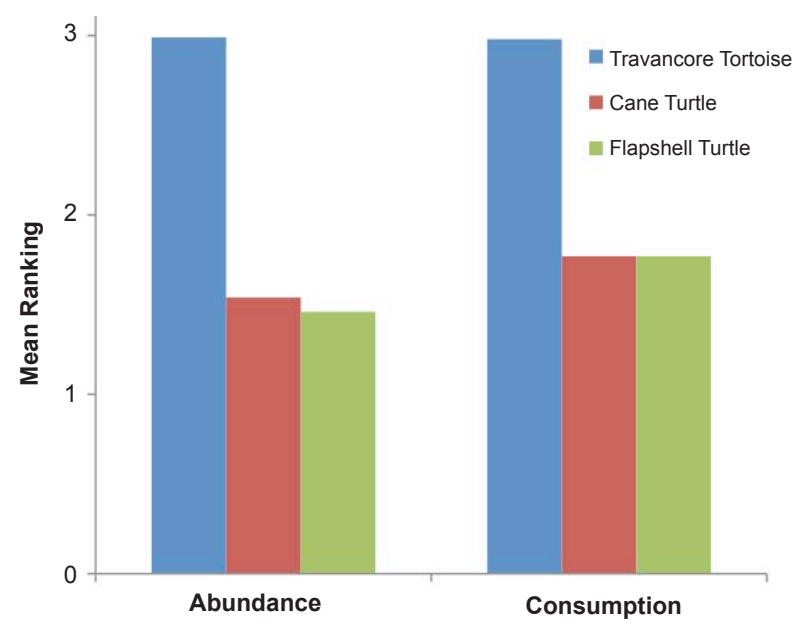

(3 = most abundant/consumed, 1 = least abundant/consumed)

Figure 2. Overall mean ranking of abundance and consumption of the three chelonian species as per respondent ranking

Table 1. Local (Malayalam) names used in the study area for three chelonian species

\begin{tabular}{|l|l|l|l|}
\hline Forest Range & Indotestudo travancorica & Vijayachelys silvatica & Lissemys punctata \\
\hline Athirapilly & Chooral aama & Chooral aama & Vellam aama \\
\hline Sholayar & Kaar aama, Saadha aama & Chooral aama & Vellam aama \\
\hline Vazhachal & Kaar aama, Saadha aama, Vella aama & Chooral aama & Vellam aama \\
\hline Kollathirumedu & Kaar aama & Chooral aama & Vellam aama \\
\hline Vellikulungara & Saadha aama & Chooral aama & Vellam aama \\
\hline
\end{tabular}




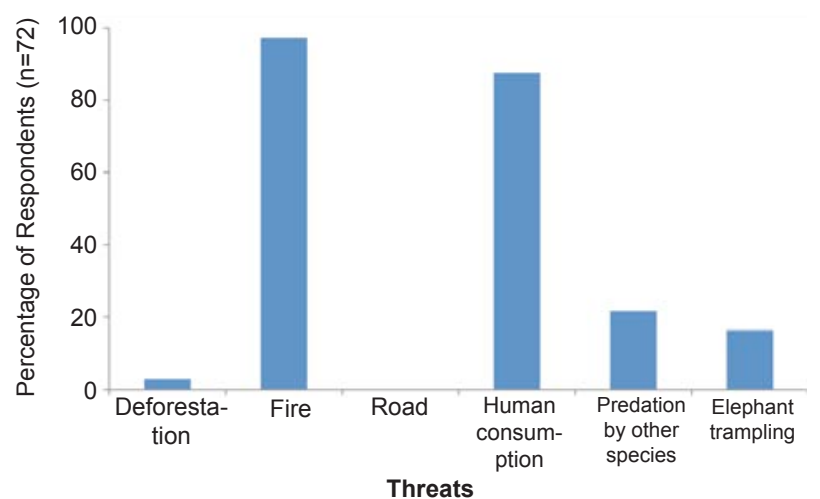

Figure 3. Threats faced by Indotestudo travancorica and Vijayachelys silvatica in the study area

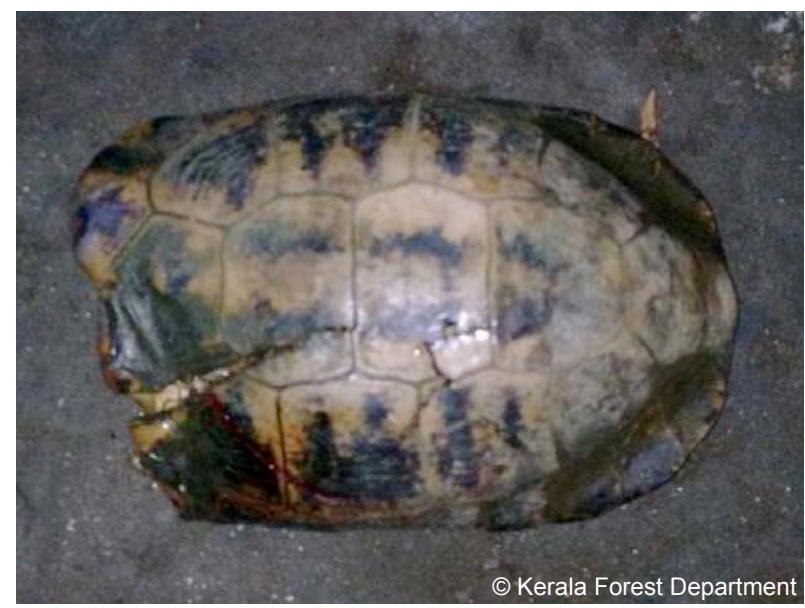

Image 3. An Indotestudo travancorica perceived to be dead from trampling by an elephant at Athirapilly Forest Division

reported (Image 3). Chelonians and elephants were believed to encounter one another regularly as they frequented the same water sources and habitats, which led to the trampling. It was perceived that causalities would not occur if chelonians were on relatively soft substrata. Otherwise it resulted in their instant death, or depending on the extent of how cracked the carapace was, it either fused back or the individual expired later.

A majority of respondents associated the presence of cane turtles to areas where the temperature was low, close to water sources, under leaf litter and close to "chooral" (Calamus rheedi) and "eatta" (Ochlandra travancorica) (Fig. 4a) especially during the rainy season and fruiting of "mootal thuri" (Baccaurea courtallensis) and "punna" (Dillenia pentagyna) (Fig. 4b). Sightings of $V$. silvatica were perceived by $13.9 \%$ of the respondents $(n=10)$ to have increased in

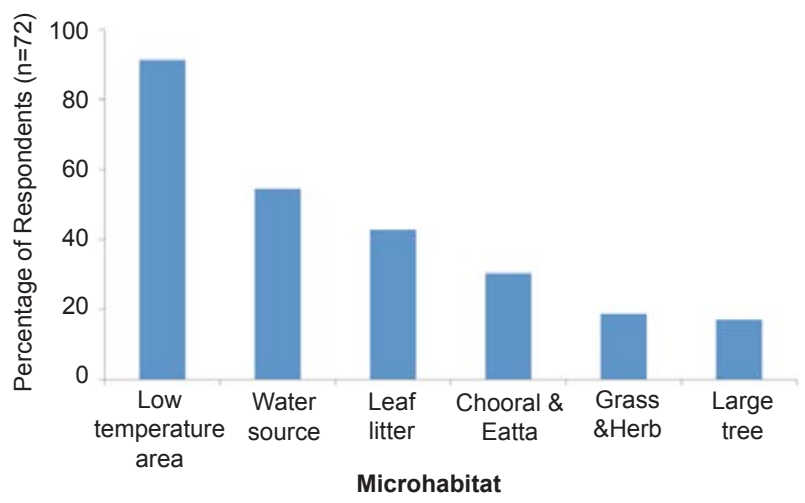

Figure 4a. Typical microhabitats associated by respondents to Vijayachelys silvatica in the study area

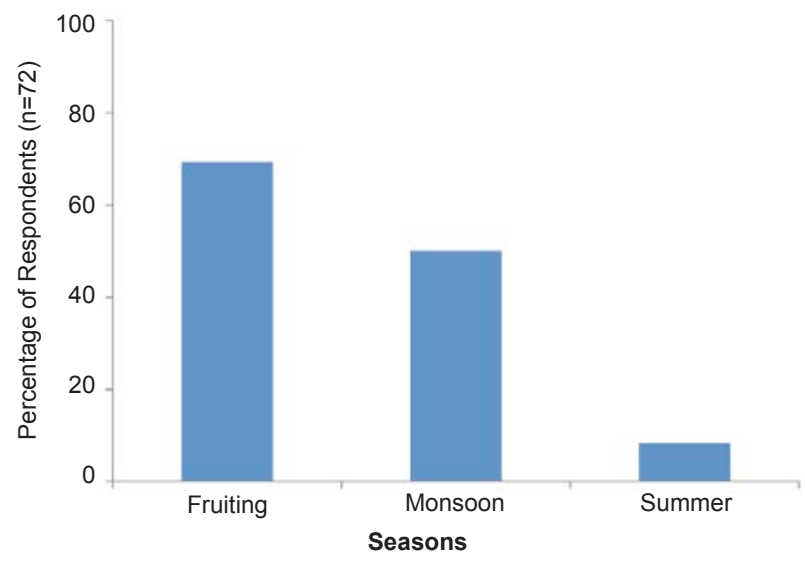

Figure 4b. Seasons associated by respondents to sightings of Vijayachelys silvatica in the study area

frequency during lightning, which caused the turtles to move out into the open. There was some overlap in the sites listed, in spite of the respondents belonging to different settlements, communities and forest ranges (Appendix 1). Contrary to existing information, $V$. silvatica was considered to be common by $79.2 \%$ of the respondents $(n=57)$ and rare by the rest. A majority of the respondents $(61.1 \%, n=44)$ believed that the population was not declining, $8.35 \%$ believed they were declining, $22.2 \%$ believed that the populations may be declining while $8.35 \%$ did not know of any change in population. 


\section{DISCUSSION}

The type specimen of $V$. silvatica was obtained from the Kadars, and their LEK facilitated the rediscovery of the turtle providing basic ecological information (Moll et al. 1986). However, a recent study states that this community has "little knowledge" of the species (Vasudevan et al. 2010). Our study strongly suggests otherwise, and is largely in conjunction with the ecology of the species assimilated through field-based surveys and local perceptions (Vijaya 1982a; Moll et al. 1986; Whitaker \& Vijaya 2009). In addition, it provides a list of possible sites of occurrence (Appendix I) that could inform future surveys. Local ecological knowledge reports the occurrence of turtles under leaf litter, which has been reported by field studies (Moll et al. 1986; Appukuttan 1991; Deepak \& Vasudevan 2009). They were also reported to be encountered more often during the rainy season than in the dry season, which could be from an increased activity during the rains (Deepak \& Vasudevan 2009). However, in contrast to other studies, which suggest nonaffinity, locals related $V$. silvatica with water sources (Groombridge et al. 1984; Moll et al. 1986; Deepak \& Vasudevan 2009). Local ecological knowledge, like that from the past, continued to relate the turtles with cane (Calamus sp.). Although some field studies have found the turtles in the vicinity of these canes (Vijaya 1982b; Appukuttan 1991; Jose et al. 2007) others have not (Groombridge et al. 1984; Moll et al. 1986). Also similar is their occurrence close to reed bamboo C. rheedi (Vijaya 1982a; Vasudevan et al. 2010). Our study like others also related $V$. silvatica to herbaceous plants but not fallen logs or rocky terrain (Vijaya 1982b; Moll et al. 1986; Vasudevan et al. 2010). Previous studies also suggested a larger abundance of the species in evergreen and semievergreen forests (Vijaya 1984; Vasudevan et al. 2010), which is probably what the LEK regarding lower temperatures and large trees implied.

Our results suggesting a higher perceived abundance of I. travancorica compared to V. silvatica in the study area is similar to the perceptions of the same indigenous community three decades ago (Vijaya 1982b) and another field-based study two decades ago (Appukuttan 1991). However, other studies contradict this, suggesting otherwise (Groombridge et al. 1984; Deepak \& Vasudevan 2009; Vasudevan et al. 2010).
This difference could have resulted from $V$. silvatica being more abundant than I. travancorica due to habitat differences, differences in survey techniques, the effect of forest fires, from the higher consumption of I. travancorica and/or local taboos.

Forest fires which was perceived as a threat by a majority $(97.2 \%, \mathrm{n}=70)$ of our respondents and by past studies (Appukuttan 1991; Vasudevan et al. 2010) does not always cause fatality among chelonians. Individuals have been known to survive fires with some degree of external injury (Ramesh 2004). Moreover, incidents of forest fires have reduced in this area during recent years (Bachan et al. 2011).

Consumption by local communities was the second most critical threat to the forest-dwelling chelonians. While consumption of $V$. silvatica by the Kadars has been reported earlier (Vijaya 1982b), reports for I. travancorica consumption exist throughout their distribution across different indigenous communities (Groombridge et al. 1984; Appukuttan 1991; Bhupathy \& Choudhury 1995; Vasudevan et al. 2010). These studies, however, did not assess the extent of consumption suggesting that it occurred only among forest-dwelling indigenous communities. Our study revealed that chelonian consumption is prevalent and not restricted to indigenous communities alone. Indotestudo travancorica, the most consumed chelonian among the respondents was also the most abundant. Consumption may therefore be influenced by abundance and most likely by their relative ease of detection as I. travancorica may be more susceptible to capture due to its larger size (Appukuttan 1991). Questionnaire surveys in adjoining forest areas (Indira Gandhi National Park and Parambikulam Wildlife Sanctuary \& Tiger Reserve) suggested that approximately one-fourth of the sample population living inside these protected areas consumed $I$. travancorica, but not $V$. silvatica (Vasudevan et al. 2010). Kadars also reside in these adjoining areas (Bachan et al. 2011) and this population along with those in our study area are related and therefore visit one another. The prominent difference in consumption intensities could have resulted from a respondent bias, small sample size interviewed or from a weaker enforcement in our study area, which is a utilitarianbased Reserve Forest, while those examined by Vasudevan et al. (2010) were strict preservationistbased National Park and Wildlife Sanctuary (IUCN 
Categories, II and IV).

The third most critical threat perceived was consumption by large carnivores and wild boars, which has been reported earlier (Vijaya 1988; Deepak \& Vasudevan 2009). Chelonians being stamped by elephants has been previously reported in the Indira Gandhi Wildlife Sanctuary, wherein an I. travancorica had survived the injuries it had so sustained (Ramesh 2004).

Local perceptions focussed on localised threats rather than the landscape level, as in the present study, the respondents did not perceive deforestation and roads as serious threats. Moreover, no respondent mentioned dams and hydroelectric projects as a possible threat; maybe because they relate it to a general 'loss of forest'.

\section{CONCLUSION}

Information derived from LEK has rarely been used in species assessments as a result of being perceived as an unreliable source for informing scientifically robust conservation action (Meijaard et al. 2011). This is but analogous in the case of field-based techniques, that are time-consuming and expensive (Anadón et al.
2009) especially for species that are difficult to detect. One would then need to depend, or integrate LEK with field surveys to adequately inform species assessments like that has been done for I. travancorica previously (Bhupathy \& Choudhury 1995; Ramesh 2008). One aspect where inaccuracies could crop up in LEK surveys is the use of local names for species. Certain species hold multiple local names that are used for multiple species (Pillay et al. 2011) like the case of $I$. travancorica in the present study wherein respondents categorized two chelonian species associated within a specific habitat as the same. We therefore suggest that interviews bealways conducted after confirming species identity through photographs, and the secondary use thereof of local names to increase the accuracy of LEK surveys. Fire and human consumption (primarily $I$. travancorica) are the two major threats in accordance to LEK that need to be mitigated to support chelonian conservation in this landscape.

\section{REFERENCES}

Anadón, J.D., A. Giménez, R. Ballestar \& I. Pérez (2009). Evaluation of local ecological knowledge as a method for collecting extensive data on animal abundance. Conservation Biology 23: 617-625.

Appendix 1. Local sites where Vijayachelys silvatica were perceived to occur with reference to human settlement, forest range, community type and number of respondents interviewed

\begin{tabular}{|c|c|c|c|c|c|}
\hline No & Settlement & Forest Range & Community Type & $\begin{array}{l}\text { Number of } \\
\text { respondents }\end{array}$ & Local sites of occurrence \\
\hline \multirow[b]{2}{*}{1} & \multirow[b]{2}{*}{ Athirapilly * } & \multirow[b]{2}{*}{ Athirapilly (a) } & Malayar & 3 & \multirow{2}{*}{$\begin{array}{l}\text { Below the waterfalls; opposite side of the river at the } \\
\text { waterfalls; Chathanpaara; Chaarpa; Ezhattumugham; } \\
\text { Kannankuzhi; Karadipaara; Karanthodu; Kodakullam; } \\
\text { Manjanam Kuthu; Munipaara; Ulasseri; Vadapaara }\end{array}$} \\
\hline & & & $\begin{array}{l}\text { Nonindigenous/ } \\
\text { Immigrants }\end{array}$ & 10 & \\
\hline 2 & Thavalakuzhipaara & Sholaiyar (b) & Malayar & 8 & $\begin{array}{l}\text { Adavara; Churaivalichapaara; Kummatti; Mechapuly; } \\
\text { Thoduthoi, Thottipetti; Thumbikaipaara }\end{array}$ \\
\hline 3 & Pokayilapaara & Vazhachal (c) & Kadar & 8 & $\begin{array}{l}\text { Ammani Pocket; Edinjapaalam; Karanthodu; Pachila } \\
\text { Valam; Paradi; Valiyapaara }\end{array}$ \\
\hline 4 & Poringalkuthu & Vazhachal & Kadar & 11 & $\begin{array}{l}\text { Gundurmedu; Karimala Gopuram; Kumlekody; Paradi; } \\
\text { Thendankuzhy; Thottapaara; Valiyapaara Thodu }\end{array}$ \\
\hline 5 & Siddhan Pocket & Vazhachal & Kadar & 4 & Ambalapaara; Karanthodu; Mukkampuzha \\
\hline \multirow[b]{2}{*}{6} & \multirow[b]{2}{*}{ Vazhachal } & \multirow[b]{2}{*}{ Vazhachal } & Kadar & 11 & \multirow{2}{*}{$\begin{array}{l}\text { Near Iron-bridge; Power House; Chaarpa; } \\
\text { Gundurmedu; Karanthodu; Lakshmi; Pachalakadu } \\
\text { Panjanamkuthu; Valiyapaara }\end{array}$} \\
\hline & & & $\begin{array}{l}\text { Nonindigenous/ } \\
\text { Immigrants }\end{array}$ & 1 & \\
\hline \multirow{2}{*}{7} & \multirow{2}{*}{ Watchmaram } & \multirow{2}{*}{ Kollathirumedu (d) } & Kadar & 5 & \multirow{2}{*}{$\begin{array}{l}\text { Adavara,; Kalakallu; Kumatti mala; Sholayar Dam Side; } \\
\text { Valichapaara; Veettikunnu Vakam; Veeramudi Mala; } \\
\text { Vachumaram Kuthu }\end{array}$} \\
\hline & & & Malayar & 6 & \\
\hline 8 & Aanappandham\# & Vellikulungara (e) & Kadar & 5 & Kavalai; Komalapaara; Nadukani; Thativara \\
\hline
\end{tabular}

* The results from this settlement need to be used with caution since respondents described both Vijayachelys silvatica and Indotestudo travancorica with the same local name

\#Within the Chalakudy Forest Division, while all the others settlements are in the Vazhachal Forest Division 
Appukuttan, K.S. (1991). Cane Turtle and Travancore Turtle - a survey report. KFRI, Peechi, India, 21pp.

Asian Turtle Trade Working Group (2000a). Vijayachelys silvatica. In: IUCN 2011. 2011 IUCN Red List of Threatened Species. $<$ www.iucnredlist.org $>$ Downloaded on 29 August 2011.

Asian Turtle Trade Working Group (2000b). Indotestudo travancorica. In: IUCN 2011. 2011 IUCN Red List of Threatened Species. <www.iucnredlist.org> Downloaded on 29 August 2011.

Asian Turtle Trade Working Group (2000c). Lissemys punctata. In: IUCN 2011. 2011 IUCN Red List of Threatened Species. $<$ www.iucnredlist.org $>$ Downloaded on 09 August 2011.

Bachan, A.K.H., R. Kannan, S. Muraleedharan \& S. Kumar (2011). Participatory conservation and monitoring of Great Hornbills and Malabar Pied Hornbills with the involvement of endemic kadar tribe in the Anamalai hills of southern western ghats, India. The Raffles Bulletin of Zoology 24: 37-43

Bhupathy, S. (2009). Status, distribution and ecology of the Indian Flapshell Turtle Lissemys punctata. In: Vasudevan, K. (ed.). Freshwater Turtles and Tortoises of India. ENVIS Bulletin: Wildlife and Protected Areas. Wildlife Institute of India, Dehradun.

Bhupathy, S. \& B.C. Choudhury (1995). Status, Distribution and Conservation of the Travancore Tortoise Indotestudo forstenii in the Western Ghats. Journal of the Bombay Natural History Society 92: 16-21.

Bhupathy, S. \& V.S. Vijayan (1993). Aspects of the feeding ecology of Lissemys punctata (Reptilia: Trionychidae) in Keoladeo National Park, Bharatpur, India. Hamadryad 18: $13-16$.

Bhupathy, S. \& V.S. Vijayan (1994). Aestivation of turtles in Keoladeo National Park, Bharatpur with special reference to Lissemys punctata (Reptilia: Trionychidae). Journal of the Bombay Natural History Society 91(3): 398-402.

CFH/MCBT (2006). Conservation Action Plan for Endangered Freshwater Turtles and Tortoises of India. Madras Crocodile Bank Trust, Post Bag 4, Mamallapuram, Tamil Nadu, South India.

Das, I. (1991). Colour Guide to the Turtles and Tortoises of the Indian Subcontinent. R \& A Publishing Limited, Portishead, 133pp.

Das,I.\&S.Bhupathy(2009).Melanochelystrijuga (Schweigger 1812) - Indian Black Turtle. In: Rhodin, A.G.J., P.C.H. Pritchard, P.P. van Dijk, R.A. Saumure, K.A. Buhlmann, J.B. Iverson \& R.A. Mittermeier (eds.). Conservation Biology of Freshwater Turtles and Tortoises: A Compilation Project of the IUCN/SSC Tortoise and Freshwater Turtle Specialist Group. Chelonian Research Monographs No. 5, pp. 038.1-038.9, doi:10.3854/crm.5.038.trijuga.v1.2009, http://www.iucn-tftsg.org/cbftt/

Deepak, V. \& K. Vasudevan (2009). Endemic turtles of India. In: Vasudevan, K. (ed.). Freshwater Turtles and Tortoises of India. ENVIS Bulletin: Wildlife and Protected Areas.
Wildlife Institute of India, Dehradun.

Deepak, V., M. Ramesh., S. Bhupathy \& K. Vasudevan (2011). Indotestudo travancorica (Boulenger 1907) Travancore Tortoise. In: Rhodin, A.G.J., P.C.H. Pritchard, P.P. van Dijk, R.A. Saumure, K.A. Buhlmann, J.B. Iverson \& R.A. Mittermeier (eds.). Conservation Biology of Freshwater Turtles and Tortoises: A Compilation Project of the IUCN/SSC Tortoise and Freshwater Turtle Specialist Group. Chelonian Research Monographs No. 5, pp. 054.1054.6, doi:10.3854/crm.5.054.travancorica.v1.2011, http:// www.iucn-tftsg.org/cbftt/.

Gilchrist, G., M. Mallory \& F. Merkel (2005). Can local ecological knowledge contribute to wildlife management? Case studies of migratory birds. Ecology and Society 10: 20.

Groombridge, B., E.O. Moll \& J. Vijaya (1984). Rediscovery of a rare Indian turtle. Oryx 17: 130-134.

Gupta, A. (2000). The beleagured chelonians of northeastern India. Turtle and Tortoise Newsletter 6: 16-17.

Hoffmann, M., C. Hilton-Taylor, A. Angulo, M. Böhm, T.M. Brooks, S.H.M. Butchart, K.E. Carpenter, J. Chanson, B. Collen, N.A. Cox, W.R.T. Darwall, N.K. Dulvy, L.R. Harrison, V. Katariya, C.M. Pollock, S. Quader, N.I. Richman, A.S.L. Rodrigues, M.F. Tognelli, J. Vié, J.M. Aguiar, D.J. Allen, G.R. Allen, G. Amori, N.B. Ananjeva, F. Andreone, P. Andrew, A.L.A. Ortiz, J.E.M. Baillie, R. Baldi, B.D. Bell, S.D. Biju, J.P. Bird, P. BlackDecima, J.J. Blanc, F. Bolaños, W. Bolivar-G., I.J. Burfield, J.A. Burton, D.R. Capper, F. Castro, G. Catullo, R.D. Cavanagh, A. Channing, N.L. Chao, A.M. Chenery, F. Chiozza, V. Clausnitzer, N.J. Collar, L.C. Collett, B.B. Collette, C.F.C. Fernandez, M.T. Craig, M.J. Crosby, N. Cumberlidge, A. Cuttelod, A.E. Derocher, A.C. Diesmos, J.S. Donaldson, J.W. Duckworth, G. Dutson, S.K. Dutta, R.H. Emslie, A. Farjon, S. Fowler, J. Freyhof, D.L. Garshelis, J. Gerlach, David J. Gower, T.D. Grant, G.A. Hammerson, R.B. Harris, L.R. Heaney, S.B. Hedges, J. Hero, B. Hughes, S.A. Hussain, J.M. Icochea, R.F. Inger, N. Ishii, D.T. Iskandar, R.K.B. Jenkins, Y. Kaneko, M. Kottelat, K.M. Kovacs, S.L. Kuzmin, E.L. Marca, J.F. Lamoreux, M.W.N. Lau, E.O. Lavilla, K. Leus, R.L. Lewison, G. Lichtenstein, S.R. Livingstone, V. Lukoschek, D.P. Mallon, P.J.K. McGowan, A. McIvor, P.D. Moehlman, S. Molur, A.M.Alonso, J.A. Musick, K. Nowell, R.A. Nussbaum, W. Olech, N.L. Orlov, T.J. Papenfuss, G. Parra-Olea, W.F. Perrin, B.A. Polidoro, M. Pourkazemi, P.A. Racey, J.S. Ragle, M. Ram, G. Rathbun, R.P. Reynolds, A.G.J. Rhodin, S.J. Richards, L.O. Rodríguez, S.R. Ron, C. Rondinini, A.B. Rylands, Y.S. de Mitcheson, J.C. Sanciangco, K.L. Sanders, G. Santos-Barrera, J. Schipper, C. SelfSullivan, Y. Shi, A. Shoemaker, F.T. Short, C. SilleroZubiri, D.L. Silvano, K.G. Smith, A.T. Smith, J. Snoeks, A.J. Stattersfield, A.J. Symes, A.B. Taber, B.K. Talukdar, H.J. Temple, R. Timmins, J.A. Tobias, K. 
Tsytsulina, D. Tweddle, C. Ubeda, S.V. Valenti, P.P.van Dijk, L.M. Veiga, A. Veloso, D.C. Wege, M. Wilkinson, E.A. Williamson, F. Xie, B.E. Young, H.R. Akçakaya, L. Bennun, T.M. Blackburn, L. Boitani, H.T. Dublin, G.A.B. da Fonseca, C. Gascon, T.E. Lacher Jr., G.M. Mace, S.A. Mainka, J.A. McNeely, R.A. Mittermeier, G.M. Reid, J.P Rodriguez, A.A. Rosenberg, M.J. Samways, J. Smart, B.A. Stein \& S.N. Stuart. (2010). The impact of conservation on the status of the world's vertebrates. Science 330: 1503-1509.

James, D.A., A.K.H. Bachan \& R. Kannan (2011). Installation of artificial nest cavities for the endangered Great Hornbill: A pilot study in southern India. The Raffles Bulletin of Zoology 24: 73-76.

Jose, J., K.K. Ramachandran \& P.V. Nair (2007). Occurrence of the Forest Cane Turtle Geoemyda silvatica (Reptilia, Testudines, Bataguridae) from a Myristica swamp of Kulathupuzha Forest Range, Southern Kerala. ENVIS Newsletter 3: 3-4.

Krishnakumar, K., R. Raghavan \& B. Pereira (2009). Protected on paper, hunted in wetlands: Exploitation and trade of freshwater turtles (Melanochelys trijuga coronata and Lissemys punctata punctata) in Punnamada, Kerala, India. Tropical Conservation Science 2: 363-373.

Lescureux, N., J.D.C. Linnell, S. Mustafa, D. Melovski, A. Stojanov, G. Ivanov, V. Avukatov, M. Von Arx \& B. Urs (2011). Fear of the unknown: Local knowledge and perceptions of the Eurasian lynx Lynx lynx in western Macedonia. Oryx 45: 600-607.

Meijaard, E., K. Mengersen, D. Buchori, A. Nurcahyo, M. Ancrenaz, S. Wich, S.S.U. Atmoko, A. Tjiu, D. Prasetyo, Nardiyono, Y. Hadiprakarsa, L. Christy, J. Wells, G. Albar \& A.J. Marshall (2011). Why don't we ask? A complementary method for assessing the status of great apes. PLoS One 6: e18008.

Moll, E.O., B. Groombridge \& J. Vijaya (1986). Rediscription of the cane turtle with notes on its natural history and classification. Journal of the Bombay National History Society 83: 112-126.

Nair, T. (2011). Decentralisation and the cultural politics of natural resource management in Kerala, India. Envirnomental Justice and Global Citizenship, Oxford, U.K.

Newing, H. (2010). Conducting Research in Conservation: Social Science Methods and Practice. Routledge, London.

Pasha, M.K.S., R. Dutta \& S. Sinha (2009). Illegal trade of fresh water turtles and tortoises in India. In: Vasudevan, K. (ed.). Freshwater Turtles and Tortoises of India. ENVIS Bulletin: Wildlife and Protected Areas. Wildlife Institute of India, Dehradun.
Pillay, R., A.J.T. Johnsingh, R. Raghunath \& M.D. Madhusudan (2011). Patterns of spatiotemporal change in large mammal distribution and abundance in the southern Western Ghats, India. Biological Conservation 144: 15671576.

Ramesh, M. (2004). A note on external injury in wild Travancore Tortoises (Indotestudo travancorica). Reptile Rap 6: 1.

Ramesh M. (2008). Preliminary survey of Indotestudo travancorica (Testudinidae) at the Indira Gandhi Wildlife Sanctuary, southern India. Hamadryad 33: 118-120.

Ravaloharimanitra, M., T. Ratolojanahary, J. Rafalimandimby, A. Rajaonson, L. Rakotonirina, T. Rasolofoharivelo, J.N. Ndriamiary, J.Andriambololona, C. Nasoavina, P. Fanomezantsoa, J.C. Rakotoarisoa, Youssouf, J. Ratsimbazafy, R. Dolch \& T. King (2011). Gathering local knowledge in Madagascar results in a major increase in the known range and number of sites for critically endangered Greater Bamboo Lemurs (Prolemur simus). International Journal of Primatology 32: 776792.

Stuart, B.L. \& J. Thorbjarnarson (2003). Biological prioritization of Asian countries for turtle conservation. Chelonian Conservation and Biology 4: 642-647.

Turtle Conservation Coalition (2011). Turtles in trouble: The world's $25+$ most endangered tortoises and freshwater turtles 2011. In: Rhodin, A.G.J., A.D. Walde, B.D. Horne, P.P. van Dijk, T. Blanck \& R. Hudson (eds.). IUCN/ SSC Tortoise and Freshwater Turtle Specialist Group; Turtle Conservation Fund; Turtle Survival Alliance; Turtle Conservancy; Chelonian Research Foundation; Conservation International; Wildlife Conservation Society and San Diego Zoo Global, Lunenburg.

Vasudevan, K., B. Pandav \& V. Deepak (2010). Ecology of Two Endemic Turtles in The Western Ghats. Wildlife Institute of India, Dehradun, 74pp.

Vijaya, J. (1982a). Rediscovery of the Forest Cane Turtle (Heosemys silvatica) of Kerala. Hamadryad 7: 2-3.

Vijaya, J. (1982b). Rediscovery of the Forest Cane Turtle Heosemys (Geomyda) Silvatica (Reptilia, Testudines, Emydidae) from Chalakudy forests in Kerala. Journal of the Bombay National History Society 79: 676-677.

Vijaya, J. (1984). Cane Turtle (Heosemys silvatica) study project in Kerala. Hamadryad 9: 4.

Vijaya, J. (1988). Status of the Forest Cane Turtle (Geomyda silvatica). Hamadryad 13: 10.

Whitaker, N. \& J. Vijaya (2009). Biology of the Forest Cane Turtle Vijayachelys silvatica, in south India. Chelonian Conservation and Biology 8: 109-115.

Zar, J.H. (2010). Biostatistical Analysis- $5^{\text {th }}$ Edition. Pearson Prentice-Hall, New Jersey, 944pp. 
Author Details: Arun Kanagavel, keen on research that would inform conservation action, is interested in social dimensions that influence perception of nature and its conservation and the potential of local communities in linking biodiversity conservation and protected areas.

RAJEEV RAGHAVAN is interested in interdisciplinary research that is focused on generating information and developing methods to support conservation decision making. He is particularly interested in conservation issues in freshwater ecosystems of the Western Ghats.

Author Contribution: AK undertook field work, collected data and carried out the analysis. AK and RR wrote the manuscript.

Acknowledgements: The first author would like to thank Fibin Baby and S. Rajkumar for helping with data collection; Baiju, P.A. Kanagavel, Vijayalakshmi and the many officials at Aanakayam, Athirapilly, Pokayilapara, Vazhachal and Vellikulangara forest stations for their assistance in field logistics; K.H. Amita Bachan for sharing shape files of the study area; Susanna Paisley and Peter Bennett (DICE, University of Kent, Canterbury, UK) for their help during the project formulation stage; Helen Meredith and Jonathan Baillie (ZSL, London) for useful discussions. This study would not have materialized if not for the participation of the local communities at the study sites. The authors also thank three anonymous reviewers and the subject editor for their comments and suggestions which greatly improved the manuscript. The study was carried out with official permission from the Kerala State Forest and Wildlife Department (WL 12-7326/2010) and financially supported by the Zoological Society of London (ZSL) Erasmus Darwin Barlow Expedition grant 2010 to the first author. 